\title{
THINKING STYLES AND ITS RELATIONSHIP TO SELF-IMAGE AMONG WOMEN IN KURDISTAN REGION/ IRAQ
}

\author{
FATIMA HASHEM DARWESH and MOAID ISMAIL JARJIS \\ Dept. of educational and psychological counseling, College of Education, University of Salahaddin, \\ Kurdistan Region - Iraq
}

(Received: February 19, 2020; Accepted for Publication: June 21, 2020)

\begin{abstract}
Purpose: thinking styles are important because collaboration and communication can be difficult if thinking differences are not acknowledged and addresses. Importantly, thinking style and identity are strongly statistically related. As, self-image has directly an affect on person's feeling, thinking, behaving in the environment. The study firstly, aimed to measure the level of thinking styles and Self-image among participants then secondly to examine statistical differences in both variables according to 'occupations and governorates'. And lastly it aimed to discover the relationship between thinking styles and self-image among women in Kurdistan Region/ Iraq.

Methods: 250 women were selected from two governorates 'Erbil and Sulaymaniyeh =125 in each'. To measure thinking styles, the study relied on (Sternberg \& Wanger, 1994) scale, which generally consisted of 140 items and divided to 5 factors (Function, Form, Level, Scope and Leaning) and 13 subscales. However, the researchers used the short version of the scale that consisted of 60 items. To measure selfimage, the study prepared the scale through relaying on exploratory method and a part of Offer self-image questionnaire-1992 (OSIQ) and adopting the theory of Carl Rogers. The thinking styles scale consisted of 60 items with the percentage of validity $(85 \%$ and over) and reliability $(86 \%)$ as well as the reliability for each styles of thinking was (Function 76\%, Form 84\%, Level 77\%, Scope $79 \%$ and Leaning 80\%). The second scale consisted of 24 items with the percentage of validity $(85 \%)$ and reliability $(85 \%)$.

Results: the results showed that the level of all styles of thinking were significant among women. However, the level of self-image was low among participated women and it is significant for the benefit to society. There were also significant differences between the variable occupations and the only two styles of thinking (form and leaning), however there were no significant main differences between the variable governorates and all styles of thinking. Regarding self-image, the result showed no significant differences between neither occupation and self-image, or governorates and self-image. To fulfill the last aim of the study, result found a positive relationship and statistically significant between self-image and the only two styles of thinking (Function and Form).

Conclusions: it is suggested that future researches are needed to further explore the relation between different variables and other demographic factors with both self-image and thinking styles
\end{abstract}

KEY WORDS:- Thinking Styles, Self-Image \& Women in Kurdistan/ Iraq

\subsection{Research Problem \\ Jowadays, the majority of people make 1 generalization that those who look} beautiful are much more happier, friendly, honorable and respectable than those who do not look beautiful or seem just fine. But despite that, how a person feel and imagine about his/her self determine how they behave and think about themselves in relation to others. So, if a person feels positive about his/her body and self then they think also positively and behave positively in relation to others, and the reverse is also true. Despite this, the researchers also wonder why individual's view of his/her self weakness and become disordered to such an extent that is could lead to low self-structures, low self-image or body image rejection, depression, anxiety, being ashamed or scared to make any relationship and even suicide attempt at the end?

According to Sternberg (1997), the cause of failure and not being successful in different situation in life among many people is related to "how they think" (Heidari and Bahrami, 2012, p. 723). Also, it has been found that all dimensions of thinking styles are important and essential for the identity development among young people especially, developing in skills and selfgovernment, managing emotions, establishing identity, freeing interpersonal relationships (Zhang, 2008, p. 257). For example, individuals with low self-structure may think negatively 
means they think that they are not important enough or special enough in relationship, in order to be deserving of their partner. So, they believe that they are lucky even to have a company. Fortunately, thinking styles help reinforce these negative thoughts that are especially found in low self-structured person (Brown, Dutton \& Cook, 2001, p. 210-213).

Generally word and especially women are surrounded by so many rapid changes and undesirable events in life, which has the most dramatic impact on everyone's lives. Unfortunately, when a person with poor selfconcept and has a lot of negative thoughts, then they have no control or choice as to how they want to live their life and how to face this situations. Salter-Pedneault (2019), reported that if a person has a strong identity it allows him to develop self-esteem and can help him to adapt to changes and face unwanted events, while the world around him is constantly changing. $\mathrm{He}$ also mentioned that without a strong sense of self in person, changes and any negative events could feel chaotic and even terrifying (para. 1-6).

Unfortunately, Kurdish women have been sacrificed a lot of times in their history of wars and genocides. Unsurprisingly, after that history the number of men have been reduced and a lot of women became widows and orphans, hence they worked outside or sought assistance. According to Omar (2010), 33\% of those Kurdish women have no sources of support. Hence, in this case, Kurdish women have faced a lot of social, physical and psychological problems; such as sexual abuse, social delusion, physical injuries, personality disorders, depression, panic and anxiety. It is clear that after wars women are always the most suffering victims. The problem of the current research is that our Kurdish society has passed through harsh conditions in different situations of life, and did not achieve enough mental health continuously. And these harsh conditions led various psychological, mental, social and economical pressures and negatively affected society.

\subsection{Research Importance}

In (1980) thinking styles, which is considered a kind of intelligence styles, introduced by (Harrison and Bramson, 1988) in communications and psychology (Chaiyapornpattana and Wongwanich, 2013, p. 2-3). What is very important to a good psychological health, is how we perceive or think about ourselves and what kind of picture we have about ourselves? Those who can highly integrate their skills and experiences into their self-structure are those with a healthy personality. Obviously, a healthy person could be able to act and interact normally with other people and achieve what they aimed for. However, if a person suffers from different kind of psychological and mental disorder then they act and behave in different ways that will affect his life. Importantly, perceiving and having healthy and unhealthy self-structures is depending on an individual's personal feelings and perspectives. Means if a person influenced by other people's opinions not adapting to their own mind and thoughts, so unsurprisingly they perceive unhealthy self-image about themselves. However, the opposite is also true.

According to Rogers, self-image has an important role so it has directly an affect on person's feeling, thinking, behaving in the environment (Ismail \& Tekke, 2015, p. 28-30). According to Rosenberg (1965) and Steiger (2014), self-structure is described as an individual's evaluation of his/her worth as a person and obviously is related to personal and social life outcomes (Rosenberg 1965; Steiger et al. 2014). In other word, some earlier studies have shown that low self-structure promote misbehavior, poor health and limited economic prospects in society while, high self-structure expect better social relationships, job performance and educational attainment in society (Rosenberg 1965, p. 2; Donnellan et al., 2005, p. 328-329).

Today, women's health is taking on a higher position in society because the health of families and communities are tied to the health of women. It is clear that a mother with a healthy mind and body will give a birth to a healthy child. Also, people realized that while women have many of the diseases as men, however their symptoms and the way of treatments might not always be the same. According to Pinquart \& Sorensen (2001), expected that women have more negative self-concept compared to men as they are at higher risk of being widowed, having health problems and needing care. Being healthy and living independently may be a source of having positive and good view of self, however, being illness or having any physical disabilities may worse the quality of social relationship which lead to a low self-concept among women (p. 197). It has to be noticed that, society is another biggest block of a workingwomen's life, after home and office. It is clear that the way of 
women's thinking influence not only family but also societies.

\subsection{Aims}

1. Measuring the level of thinking styles according to all five (5) factors and thirteen (13) subscales among women in Kurdistan/ Iraq.

2. Measuring the level of Self-image (SI) among women in Kurdistan/ Iraq.

3. Examining statistical differences in thinking styles 'in each style', according to factors (occupation and governorates) among women in Kurdistan.

4. Examining statistical differences in variable self-image according to factors (occupation and governorates) among women in Kurdistan.

5. Discovering the relationship between both variable, thinking styles (all styles) and selfimage among women in Kurdistan/ Iraq.

\subsection{Limitations}

The current research (2017-2020) has been consisted of the Kurdish women in the Kurdistan Region of Iraq/ both governorates (Erbil and Sulaymaniyeh).

\subsection{Theoretical Definitions \\ 1.5.1 Thinking Styles}

Albrecht (1983) who said that thinking styles are a person styles is their characteristic way of processing information. It is the way person acquire their knowledge, organize their thoughts, form their views and opinions, apply their values, solve problems, make decisions and plans and express their self to others (Albrecht, 1983).

Sternberg's (1988-1997) defined thinking styles, as "are our preferred ways of using the abilities we possess" (Zhang, 2001; p101). Stenberg's theory of mental self-government delineates 13 thinking styles that fall along 5 dimensions of mental self-government. These are (1) functions (containing the legislative; situation that requires creation, executive; situations that provide structure and judicial; situations that require evaluation), (2) forms (containing the monarchic; situations that allow complete focus on one thing or aspect at a time until it is complete, hierarchic; situations that allow creation of a hierarchy of goals to fulfill, oligarchic; situations that allow working with competing approaches and anarchic; situations that lend themselves to great flexibility of approaches), (3) levels (containing the global; situations that require engagement with large, global, abstract ideas, and local; situations that require engagement with specific, concrete details), (4) scopes (containing the internal; situations that require activities that allow one to work independently of others and external; situations that allow working with others in a group or interacting with others at different stages of progress) and (5) leanings (containing the liberal; situations that involve unfamiliarity, going beyond existing rules or procedures and conservative; situations that require adherence to existing rules and procedures) (Zhang, 2001; p101).

Sternberg \& Wagner (1994) defined thinking styles as a preferred way of thinking. It is not ability but rather how an individual uses abilities that she or he possesses (Sternberg \& Wagner, 1994).

Depending to the entire above clarifications and theoretical definitions, the researchers for their experimental study used the Sternberg \& Wagner (1994) definition and Stenberg's theory of mental self-government to measure the level of different styles of thinking among participants. Procedural definition is related to the degree to which women achieved through answering all items of the scale that used in the current study, and, according to their sociodemographic factors.

\subsubsection{Self-Image}

Rogers (1954) who identified the 'real self' is initiated by the actualizing tendency, follows organismic valuing, needs and receives positive regard and self-regard (Ismail \& Tekke, 2015).

Rogers (1959) believed that people are encouraged by animate tendency, which is the one basic motive of self. Self-image affects how a person thinks, feels and behaves in the real world. He also mentioned that, a person wans to feel, experience and behave in ways which are consistent with his/her self-image and which reflect what he/she would like to be like, his/her ideal-self (Macleod, 2014).

Rosenberg (1965) stated that an individual's self-image 'largely determines his thoughts, feelings and behavior (p. 804).'

Offer, Ostrov, Howard \& Dolan (1992) view of personality development considered individuals' age a time of change during which identity becomes stable and holds that different aspects of self develop at different times (Jacob, 1997, p. 373-379).

Baumeister (1999) provides self- concept definition; "The individual's belief about himself or herself, including the person's attributes and who and what the self is".

McLeod (2008) reported that the self-concept is 
an important term for both social and humanistic psychology.

Depending to the entire above clarifications and theoretical definitions, the researchers for their experimental study used the Calr Rogers (1954) definition and theory to measure the level of self-image among participants. Procedural definition is related to the degree to which women achieved through answering all items of the scale that used in the current study, and, according to their socio-demographic factors.

\section{LITERATURE REVIEW}

Style is a way of thinking, to modify the style is not equal with ability but it is the way to use individual abilities. In fact, it is difficult to distinguish between styles and abilities, the ability refers to the fact that how well a person can do something, but the style means how the person likes to do a job (Sternberg, 1997). Monreal (2000) reported that the concept of 'Style' is found since the 50's on studies about emotional processes regulation (Wechsler, 2009, p. 38). Thinking styles exist at the interface between cognition and personality traits. Thinking styles are preferred ways of applying one's intellectual abilities and knowledge to a problem. For example, two people may have equal levels of intelligence but differ on how they focus their abilities on a task. Research indicates that some thinking styles promote creativity, whereas other may diminish it (Lubart, 1994, p. 289). According to Sternberg's (1988), thinking styles refer to people's preferred ways of using the abilities that they have, he also classified 13 thinking styles based on the theory of mental self-government (Zhu \& Zhang, 2011, p. 362).

Different studies suggested that thinking styles are correlated with creative process, problem solving, decision-making, personality traits and educational achievement, and also different factors including culture, age, socioeconomic or occupational status, social status and above all gender are effective on thinking styles (Emamipour \& Seyf, 2004).

A study found significant differences between female and male in thinking style specially, in legislative, judicative, general, free and internal thinking styles. Male's scores was higher than female on these styles, this result are consistent with Sternberg, who addressed that men's score higher in legislative and internal thinking styles in comparison with women
(Demirbas \& Demirkan, 2007, p. 345-359; Saideh et al., 2014, p. 1). In Wechsler (2009) study, found 17-24 years old women tended to be more logical than men, however at the same years of age men tended to be more cautious.

In a strong study among 101 participants showed, those who had high level of educations with high academic major, and those who had better job quality and condition like working in education, showed more balanced thinking styles (Osterman, 2015, p. 107-115). Above all, Harrison and Bramson (2002) point out that, different thinking styles of managers in different organizations, can lead to different performance, because individual thinking styles strongly affects the analysis, relation with others, approaches, situations, organizing, solving problems, leadership and management (p. 5-10). To support this reality, in a study of 120 managers of social security organization, Ashoori, Khorshidi and Khosravi (2015) aimed to investigate the relationship between thinking styles and job of males and females managers. The results indicated that there was a significant positive correlation between the social security organization managers' thinking styles and their performance (p. 535-538).

On the other hand, identity is the whole picture of who a person believe he is, and who the person tell to himself and others that he is. According to Greenthal (2019), today's body size (Body-image) has long been a topic of concern for many young people. Unfortunately or fortunately, social media has added a new and often more critical way for people especially for teens and young adults to look at themselves and compare their bodies with other people's. In fact, the tools available to modify images, and can fix every weakness and unwanted parts of body, means allowing everyone to create an idealbody. The unfortunate truth is that, many young adults are unhappy with what they see when they look in the mirror after that. In a survey conducted by GirlGuiding (2011) half of women aged 16 to 21 said they would undergo surgery to improve their bodies. A lot of serious consequences came from poor body image, while some teens develop eating disorders; many others experience depression (para. 1-9). Another study conducted by Dave and Rashad (2009) found that girls who were unhappy with their appearances were at a significantly higher risk for suicide. People are surrounded by changes in life and it is the one thing that has the most dramatic impact on people's lives. 
Unfortunately, when a person with poor selfconcept and has a lot of negative thoughts, then they have no control or choice as to how they want to live their life

Well-being and healthy-related quality of life may be indicative adolescents' healthy development in term of all aspects such as mental health, relationships, occupations and education. Adolescent well-being is important, as it leads to a hopeful and healthy adult. A survey in Turkey (2015), reported that selfesteem and body image variables together have a significant impact on adolescents' subjective well-being. The results among 164 young people showed that self-esteem and body image perception affects the sense of subjective well being positively (Savi-Cakar \& Savi-Karayol, 2015, p. 536-551).

Zhang (2008) in the study among Chinese students from Shanghai found that those participants who had a strong sense of identity were those who achieved more levels of education and had part-time jobs with a good quality, additionally he also reported that, those students with more educational levels and holding jobs scored significantly higher on the confidence and conceptions about body and appearance subscales (p. 255-271). In contrast, in a study's results showed that the mean score of self-esteem according to different educational achievements did not differ statistically. However, there are some other factors that had a statistically significant influence on students' self-esteem, such as family economic status and marital status (Ghezelbash, Rahmani, Peyrovi, Inanloo \& Shekarchian, 2015, p. 1-5).

Importantly, it has been found that thinking style and self-image are strongly statistically related. Zhang (2001), in this study among 794 university students from Hong found a significant relationship between thinking styles and self. Meanwhile, both thinking styles and self are statistically related to the young university students' extracurricular experiences (p. 100-107). A sample of 367 students was selected in another study conducted by Negahi, Ghashghaeizadeh and Hoshmandja (2012) and results showed that the judgmental and legislative thinking styles had a significantly positive relationship with academic self-efficacy of students (p. 75-82). Zhang (2008) investigated the relationship between thinking styles and identity development among Chinese students from Shanghai. He reported that Not only were thinking styles strongly associated with identity development, but also the former had predictive power for the latter, also those students who have received more levels of education and those who worked off campus with a good quality had a stronger sense of identity (p. 255-271).

\section{THEORETICAL FRAMEWORK \\ 3.1 Thinking Styles' Theories \\ 3.1.1 Mindex Theory '1983' by Albrecht $k$.}

Another common theory clarifying thinking styles is Mindex Theory by Dr. Karl Albrecht. According to this theory thinking style is a person's characteristic way of processing information. It's the way he acquire his knowledge, organize his thoughts, form his views and opinions, apply his values, solve problems, make decisions, plans, and express himself to others. Mindex measures four basic dimensions of cognitive preference, like leftbrained and concrete; right-brained and concrete; left-brained and abstract; and right-brained and abstract. It also measures 16 additional components of mental process; which are (a) sensory mode preferences (kinesthetic, visual, auditory), (b) structure preference (time orientation, detail orientation, technical orientation, goal orientation), (c) mental flexibility (tolerance for ambiguity, opinion flexibility, semantic flexibility, positive orientation, sense of humor, investigative orientation, resistance to enculturation), (d) thinking fluency (idea fluency, logical fluency). Importantly, to make these four thinking styles easy to understand and remember, Albrecht has given them simple metaphorical names, in terms of colors. We can call the left-brained mode of thought "blue" thinking, because we tend to think of analytical people as having relatively "cool" personalities, represented by a cool color like blue. We can call the right-brained thinker a "red" thinker, because we think of intuitively inclined people as having "warmer" personalities, as suggested by red. Similarly, we can give simple metaphorical names to the other dimension the concrete and abstract levels. We can call them "earth" and "sky" respectively. "Earth" thinking is concrete, immediate, and results-oriented. "Sky" thinking is imaginary, hypothetical, and conceptual. For example, (a) red earth (right-brained and concrete), (b) blue earth (left-brained and concrete), (c) red sky (right-brained and abstract), (d) blue sky (leftbrained and abstract) (Albrecht, 1983). 


\subsubsection{Theory of Mental Self-Government by Sternberg R. ' 1988 '}

A theory of mental self-government is presented that proposes a set of intellectual styles as a bridge between intelligence and personality. According to the theory, intellectual styles can be understood as governmental in (a) function (legislative, executive, judicial), (b) form (monarchic, hierarchic, oligarchic, anarchic), (c) level (global, local), (d) scope (internal, external) and (e) leaning (conservative, progressive). A key point to understanding performance in school, work, and personal life is that people naturally seek to match their preferred intellectual styles to tasks and situations that draw upon these styles. As a result, it is necessary in counseling, diagnosis, and training, to take into account styles as well as level of intellect (Sternberg, 1988, p. 197224).

\subsubsection{Cognitive Theory}

Jean Piaget and Gagne claimed that thinking and learning are internal mental actions that take place in the brain and include sensory perception, processing of information, applying and combining information, and memory. They also mentioned that, in the model of thinking, the teacher's role is to structure experiences that will cause individuals to learn through both physical and mental activities. The importance of developmental readiness was stressed by this theory, on the other hand, experiments have showed, for instance that children below a certain age are not yet able to think in abstract terms; learning must be concrete or it will produce nothing but confusion. Regarding differences in thinking between children and adult, one of the first identifying of Piaget was that the way that children think is different from the way adults think. Instead, he proposed that intelligence is something that grows and develops through a series of stages. Older children do not just think more quickly than younger children, he suggested. Instead, there are both qualitative and quantitative differences between the thinking of young children versus older children. Based on his observations, he concluded that children were not less intelligent than adults, they simply think differently. Albert Einstein called Piaget's discovery "so simple only a genius could have thought of it" (Cherry, 2019).

\subsubsection{Social Theory}

In this model of thinking, learning occurs as a result of social interaction and the observation of human social behavior. As such, learning is more of a community endeavor than an individual one. Some social theorists include the natural environment as a part of this community of learning. The goal of thinking under this model is to achieve full participation of individuals in their respective communities; the environmental branch of this theory would add to that the goal of utilizing natural resources in a responsible and renewable manner. Albert Bandura theorized that people learn from one another via observation, imitation and modeling. The theory has often called a bridge between behaviorist and cognitive learning theories because it encompasses attention, memory and motivation. Generally speaking, the theory reported that various factors increase or decrease the amount of attention paid. On the other hand, remembering what you paid attention to, is a process of retention, which includes symbolic coding, mental images, cognitive organization, symbolic and motor rehearsal. Additionally, having a good reason to imitate will increase the process of motivation (Bandura, 1977).

* In this study the researchers depended on the first theory 'Theory of Mental Self-Government by Sternberg R. ' 1988 ' to explain and explore the variable of thinking styles.

\subsection{Self-Concept Theories}

\subsubsection{Roger's Theory of Personality}

The central concept in Rogers' theory of personality is the self-concept. The self consist of all the ideas, perceptions, and values that characterized ' $\mathrm{I}$ ' or 'Me'; it includes the awareness of 'what I am' and "what I can do.' This perceived self, in turn, influences both the person's perception of the world and his or her behavior. For instance, a woman who perceives herself as strong and competent perceives and acts upon the world quite differently from a woman who considers herself weak and ineffectual. Notably, according to this theory the self-concept does not necessarily reflect reality, means a person may be highly successful and respected but still view himself as a failure. According to Rogers, the individual evaluates every experience in relation to this self-concept. People want to behave in ways that are consistent with their self-image; experiences and feelings that are not consistent are threatening and may be denied admittance to consciousness. This is essentially Freud's concept of repression, although Rogers felt that such repression is neither necessary nor permanent (Atkinson L., Atkinson C., Smith, Bem \& Nolen-Hoeksema, 
1996, p. 464-465)

According to Rogers, self-concept includes three important components, which are selfimage, self-esteem and ideal self. Generally mentioning, self-image is the way person see his-self or herself, and self-image includes what a person know about their physically, social roles and their personality traits. On the other hand, self-esteem is the value we place upon ourselves. Individual levels of self-esteem are dependent on the way a person evaluate him or herself. Those evaluations incorporate a person's personal comparisons to others as well as others' responses to them. When a person compare himself to others and find that they are better at something than others and/or that people respond favorably to what the person do, their self-esteem in that area grows. However, when a person compare himself to others and find they are not as successful as others in a given area and also receive negative responds from people to what they do, then their self-esteem decreases. Regarding ideal self, which is the self usually a person would like to be and unfortunately, there is sometimes a difference between one's selfimage and one's ideal self, hence this unstableness can negatively impact one's selfesteem (Rogers, 1959, p. 184-256; McLeod, 2008; Baumeister, 2010, p. 139-175; Ackerman, 2018; Cherry, 2018).

\subsubsection{William James' Personality Theory '1890'}

James discusses the composition of what makes the self, and breaks it down into 'I' and 'Me' and explaining the differences and importance of each. The ' $\mathrm{Me}$ ' is explained as being the material, social and spiritual components of the ego. No one considered selfesteem as unique trait to be studied and defined until the psychologist James introduced his theory of self-esteem in 1890. He used a simple formula to explain self-esteem, stating that selfesteem equals success divided by our pretentions. Pretention refers to goals, values and what we believe about our potential. So, if our actual achievements are low and our believed potential and goals are high, we see ourselves as failures. Conversely, if your success exceeds your expectations, you feel great about yourself, and your self-esteem rises. James describes self-esteem as how we view our selfimage, and whether or not we approve of it. The idea of self-esteem is defined by our concepts and how well we like ourselves. It also links in with our inner values, which define our ego. The self-image is further described as being our social roles, body image, and personality traits. $\mathrm{He}$ also mentioned that the way that self-esteem is derived is by measuring the gap between the ideal self and the self-image. The ideal self is a person's concept of what the perfect person should be, as well as what they see as their full potential. This ideal self may be close to a person's self-image, which would mean that this person has a high self-esteem. The greater the difference between someone's self-image and ideal self be, the lower the resulting self-esteem (Moulton, 1970).

\subsubsection{Social Identity Theory '1970s' by Tajfel \& Turner}

The concept of social identity was created as a means to consider the way one conceptualizes the self-based on the social groups to which one belongs. This theory describes the conditions under which social identity becomes more important than one's identity as an individual. The theory also specifies the ways in which social identity can influence intergroup behavior. The studies demonstrated that group membership was so powerful that simply classifying people into groups is enough to make people think of themselves in terms of that group membership. Furthermore, this categorization led to in-group favoritism and out-group discrimination, indicating that intergroup conflict could exist in the absence of any direct competition between groups. The theory aimed to illuminate both the cognitive processes that lead people to define their group memberships and the motivational processes that enable people to maintain positive social identity by favorably comparing their social group to other groups. Generally speaking, this theory is built on three key cognitive components, which are social categorization, social identification and social comparison. Social categorization is the process by which we organize individuals into social groups in order to understand our social world, but social identification that is the process of identifying as a group member, and social comparison, which people compare their group with other groups in term of prestige and social standing (Tajfel \& Turner, 1979, p. 33-47; Vinney, 2019).

* In this study the researchers depended on the first theory 'Roger's Theory of Personality' to explain and explore the variable of SelfImage. 


\section{RESEARCH PROCEDURE \\ 4.1 Design of the study}

The researchers have used Descriptive and Correlation study design. Descriptive and Correlation study design is research designed to provide a snapshot of the current state of affairs and to discover relationships among variables and to allow the prediction of future events from present knowledge (Stangor, 2011). Additionally, this approach is the most common study design of research (Van Dalen, 2003. p. 334).

\subsection{Population of the study}

According to the research problems and aims, the population was determined by female living in the community in the Kurdistan Region in Iraq (KRI). According to UN Migration (2018) and the ministry of planning in Erbil, a quick count of the population of KRI was conducted at the end of 2019, which consisted of $(6,033,814)$ male and female from urban and rural. However, the targeted population of this study was only female, which is consisted of $(3,003,925)$ with differences in occupations and not workingwomen. See appendix (1)

\subsection{Sample of the study}

Sample is part of target population that used in the study; the researchers chose a random sample depending on the styles of the study. As McLeod (2019) stated that sampling is the process of selecting a representative group from the population under study, and a sample is the group of people who take part in the investigation and they referred to as 'participants'. In this regard, two governorates (Erbil and Sulaymaniyeh) were selected in the Kurdistan. Then an equal number of participants in each governorate were randomly selected, which consisted of $(n=125)$ women, and in totally $(\mathrm{N}=250)$ participants among all selected governorates; see appendix (2).

\subsection{Measurements \\ 4.4.1 Thinking Style}

To measure thinking style variable the researchers relied on shorted version of (Sternberg \& Wanger, 1994) scale, which consisted of 60 items with divided to 5 factors (Forms, Functions, Scope, levels and Leanings) and 13 subscales; see appendix (3) (Chawla, 2017, p. 30). Five alternatives were identified and determined, which were 'to a large degree, to a medium degree, to a small degree, rarely and not applied at all', and then for the purpose of insuring the validity of the scale, it has extracted indicators of face validity before using, which presented to numbers of experts and specialists in the field of educational and psychological sciences with the specialty of psychology and sociology. The scale had its face validity with a percentage of $85 \%$ and more. Also, to extract the scale reliability the study used the internal consistency method where it used an equation of Cronbach's Alpha to measure internal consistency, which was (0.93). The research used the Spearman-Brown correction for the purpose of correcting the value of the reliability so it was (0.79), which is considered as an acceptable reliability coefficient according to the items number. And when correlation coefficient value was converted to the t-test value, it was reached (6.690), which was significant at the 0.001 level. Also test-retest method, reported the Pearson Correlation Coefficient between the participants' result in both time of the test, and the correlation value for thinking styles was $\left(0.86^{* *}\right)$ and for each styles was (function $0.76^{* * /}$ form $0.84^{* * /}$ level $0.77 * *$ / scope $0.79 * *$ and leaning $0.80^{* *}$ ) and this is a high correlation, which means that the scale has a high degree of stability.

\subsubsection{Self-Image}

The study made the scale for Self-image through relaying on exploratory method and a part of Offer, Ostrov and Howard (1992) (Offer self-image questionnaire-1992) for measuring self-image, as well as, by referring to the selfimage definition that adopted in the first chapter of the study, as defined by Carl Rogers (1951). The scale consisted of 24 items, and all the scales' items were not formulated in a direction of self-image variable, or in the line with the method, so the values of the alternative answer for positive items were ranked as ' 5 for completely true of myself, to 1 for not at all true of myself" and for negative items were ranked oppositely; see appendix (4). Then for the purpose of insuring the validity of the scale, it has extracted indicators of face validity before using, which presented to numbers of experts and specialists in the field of educational and psychological sciences with the specialty of psychology and sociology. The scale had its face validity with a percentage of $85 \%$ and more. Also, to extract the scale reliability the study used the internal consistency method where it used an equation of Cronbach's Alpha to measure internal consistency, which was (0.74). The study used split-half reliability method, the reliability of the scale is (0.72), also the researchers used the Spearman-Brown correction 
for the purpose of correcting the value of the reliability so it was (0.76), which is considered as an acceptable reliability coefficient according to the items number. And when correlation coefficient value was converted to the t-test value, it was reached (4.515), which was significant at the 0.001 level. Also test-retest method, reported the Pearson Correlation Coefficient between the participants' result in both time of the test, and the correlation value was $\left(0.85^{* *}\right)$ and this is a high correlation, which means that the scale has a high degree of stability.

* After completing and evaluating the psychometric properties of the two scales (Validity and reliability), the study's instruments were applied among the study sample of 250 women, which divided equally between two governorates (Erbil and Sulaymaniyeh). After that, the researchers converted all obtained answers to data through using a statistical instrument (SPSS) that usually use in human sciences.

\section{RESULTS}

\subsection{Measuring the level of Thinking Styles according to all five (5) factors and thirteen (13) subscales among participants}

After processing and applying thinking styles measurement on 250 women as a sample of the study, the result showed that the mean degree of all the styles of thinking are [(Function $\mathrm{M}=$ 58.94) (Form $\mathrm{M}=$ 61.30) (Level $\mathrm{M}=38.49$ ) (Scope $M=37.25$ ) and (Leaning $M=33.64$ )] with a standard deviation [(Function Std.= 9.259) (Form Std.= 9.790) (Level Std.= 6.399) (Scope Std.= 7.149) and (Leaning Std.= 6.290)]. From this result, when comparing the degree of each styles' mean with the degree of each styles' hypothetical mean, which are $[(\mathrm{M}=58.94>\mathrm{HM}=$ 45) for function style, $(M=61.30>\mathrm{HM}=48)$ for form style, $(M=38.49>\mathrm{HM}=30)$ for level style, $(\mathrm{M}=37.25>\mathrm{HM}=30)$ for scope style and for the last style $(M=33.64>\mathrm{HM}=27)$ ] it can be noticed that, the all styles' mean values is greater than the hypothetical values. Hence, examining the differences between the two means with using one-sample t-test, it was found to be significant at the level of 0.001 with the degree of freedom 249. On the other hand as can be seen the T-calculated value of all styles are bigger than the all T-table value; see table (1).

\begin{tabular}{|c|c|c|c|c|c|c|c|}
\hline \multirow[b]{2}{*}{ Variable } & \multirow[b]{2}{*}{$\begin{array}{l}\text { Numbers } \\
\text { of sample }\end{array}$} & \multirow[b]{2}{*}{ Mean } & \multirow[b]{2}{*}{$\begin{array}{l}\text { Std. } \\
\text { Deviation }\end{array}$} & \multirow[b]{2}{*}{ Test Value } & \multicolumn{2}{|c|}{$T$ value } & \multirow[b]{2}{*}{ Significant } \\
\hline & & & & & Calculated & Table & \\
\hline TS (Function) & 250 & 58.94 & 9.259 & 45 & 23.811 & 1.960 & Sig. 0.001 \\
\hline TS (Form) & 250 & 61.30 & 9.790 & 48 & 21.481 & 1.960 & Sig. 0.001 \\
\hline TS (Level) & 250 & 38.49 & 6.399 & 30 & 20.982 & 1.960 & Sig. 0.001 \\
\hline TS (Scope) & 250 & 37.25 & 7.149 & 30 & 16.038 & 1.960 & Sig. 0.001 \\
\hline TS (Leaning) & 250 & 33.64 & 6.290 & 27 & 16.681 & 1.960 & Sig. 0.001 \\
\hline
\end{tabular}

According to the above results can be reported that the level of all styles of thinking were significant among participated women.

On the other hand, the research tended to found the percentage of participated women who use each of the styles of thinking. The research showed $90.8 \%$ of women use function styles,
$88 \%$ of women use form style, $88.8 \%$ of women use level style, $82 \%$ of women use scope style and $82.4 \%$ of women use leaning style. Hence, the research discovered that, 'Function Style' is the most popular style, but 'Scope Style' is the less popular style, among women in Kurdistan Region/ Iraq. 


\subsection{Measuring the level of Self-Image (SI) among participants}

After applying the self-image questionnaires among 250 participants, the result showed that the mean degree of the measurement is 64.48 with a standard deviation (6.848). From this result, when comparing this degree of mean with a hypothetical mean of the scale, which is 72 can be noticed that the former is smaller than the later. Hence, examining the differences between the two means with using one-sample t-test, it was found to be significant at the level of 0.05 with the degree of freedom 249 but for the benefit of the society. On the other hand as can be seen the T-calculated value 17.353 is bigger than the T-table value 1.960; see table (2).

Table (2) One-Sample Test to measure the level of self-image among participants

\begin{tabular}{|c|c|c|c|c|c|c|c|}
\hline \multirow[b]{2}{*}{ Variable } & \multirow[b]{2}{*}{$\begin{array}{l}\text { Numbers of } \\
\text { sample }\end{array}$} & \multirow[b]{2}{*}{ Mean } & \multirow[b]{2}{*}{$\begin{array}{l}\text { Std. } \\
\text { Deviation }\end{array}$} & \multirow[b]{2}{*}{ Test Value } & \multicolumn{2}{|c|}{$\mathrm{T}$ value } & \multirow[b]{2}{*}{ Sig. } \\
\hline & & & & & Calculated & Table & \\
\hline Self-image & 250 & 64.48 & 6.848 & 72 & 17.353 & 1.960 & 0.05 \\
\hline
\end{tabular}

* Also it is significant at the (0.01/2.59) level, and (0.001/3.31) level, as the T Calculated value in bigger than all T table value.

According to the above results can be reported that the level of self-image was low among participated women and it is significant for the benefit to society. This result are in supportive with GirlGuiding (2019) and Dave and Rashad (2009) who reported that a lot of women were unhappy with their appearances and they would undergo surgery to improve their bodies and they suffer from low self-image and poor self-concept and has a lot of negative thoughts.

5.3 Examining statistical differences in Thinking Styles 'in each style' according to participants' Occupations and Governorates.

\subsubsection{Differences in all Styles of Thinking according to Occupations variable}

Another aim of this study was to examine the statistical difference between all styles of thinking according to 250 participants' occupations. Results of One-way ANOVA showed that there is a significant main difference between the variable occupations and only two styles of thinking (form and leaning); see table (3). Occupations variable were distributed among nine groups (doctors, engineers, lawyers, teachers, employments, NGO members, students, housewife and not-occupied women). For further explanation see appendix (2).

\begin{tabular}{|c|c|c|c|c|c|c|c|}
\hline \multicolumn{8}{|c|}{ participants } \\
\hline \multirow[b]{2}{*}{ Var. } & \multirow[b]{2}{*}{$\begin{array}{l}\text { Source of } \\
\text { contrast }\end{array}$} & \multirow[b]{2}{*}{ Sum of squares } & \multirow[b]{2}{*}{$d f$} & \multirow[b]{2}{*}{$\begin{array}{l}\text { Mean } \\
\text { square }\end{array}$} & \multicolumn{2}{|l|}{$F$ value } & \multirow[b]{2}{*}{$\begin{array}{l}\text { Sig. } \\
0.05\end{array}$} \\
\hline & & & & & Calculated & Table & \\
\hline \multirow{4}{*}{$\begin{array}{l}\text { Function } \\
\text { Occupation }\end{array}$} & Between Groups & 1363.263 & 8 & 170.408 & \multirow{3}{*}{2.05} & \multirow{3}{*}{2.380} & \multirow{3}{*}{$\begin{array}{l}\text { Not } \\
\text { Sig. }\end{array}$} \\
\hline & Within groups & 19983.953 & 241 & 82.921 & & & \\
\hline & Total & 21347.216 & 249 & & & & \\
\hline & Between Groups & 1813.114 & 8 & 226.639 & & & \\
\hline Form & Within groups & 22051.386 & 241 & 91.500 & 2.477 & 2.380 & Sig. \\
\hline \multirow[t]{2}{*}{ Occupation } & Total & 23864.500 & 249 & & & & \\
\hline & Between Groups & 561.845 & 8 & 70.231 & & & Not \\
\hline Level/ & Within groups & 9634.639 & 241 & 39.978 & 1.757 & 2.380 & Sig. \\
\hline \multirow[t]{2}{*}{ Occupation } & Total & 10196.484 & 249 & & & & \\
\hline & Between Groups & 235.877 & 8 & 29.485 & & & Not \\
\hline \multirow{3}{*}{$\begin{array}{l}\text { Scope/ } \\
\text { Occupation }\end{array}$} & Within groups & 12491.247 & 241 & 51.831 & 0.569 & 2.380 & Sig. \\
\hline & Total & 12727.124 & 249 & & & & \\
\hline & Between Groups & 900.984 & 8 & 112.623 & & & \\
\hline \multirow{2}{*}{$\begin{array}{l}\text { Leaning/ } \\
\text { Occupation }\end{array}$} & Within groups & 8950.892 & 241 & 37.141 & 3.032 & 2.380 & Sig. \\
\hline & Total & 9851.876 & 249 & & & & \\
\hline
\end{tabular}


As it is shown in the above table the Fcalculated value of all styles are smaller than Ftable value expect Form and Leaning styles [(function; F-C $=2.055<\mathrm{F}-\mathrm{T}=2.380$ ), (Form; F$\mathrm{C}=2.477>\mathrm{F}-\mathrm{T}=2.380),($ level $; \mathrm{F}-\mathrm{C}=1.757<\mathrm{F}-$ $\mathrm{T}=2.380$ ), (scope; $\mathrm{F}-\mathrm{C}=0.569<\mathrm{F}-\mathrm{T}=2.380)$ and (leaning; $\mathrm{F}-\mathrm{C}=3.032>\mathrm{F}-\mathrm{T}=2.380$ ) at the degree of freedom 8-241 and the level of significance 0.05 , which means that there are significant differences in the prevalence rate of only two styles of thinking among women according to the variable occupations.

In order to determine the trend of differences the study used (Scheffe) for their second analyzes and it was found that all the values of comparison were statistically significant at the degree of freedom 0.05 ; see table (4).

Table (4) Scheffe method to show the values of the differences between means of the two styles of thinking among participants according to occupations variable

\begin{tabular}{|c|c|c|c|c|c|c|}
\hline \multicolumn{2}{|l|}{ V. } & \multirow{2}{*}{$\begin{array}{l}\text { Mean } \\
65.86\end{array}$} & \multirow{2}{*}{$\begin{array}{l}\mathrm{N} \\
27\end{array}$} & \multirow{2}{*}{$\begin{array}{c}\text { Std. deviation } \\
7.745\end{array}$} & \multirow[t]{2}{*}{ Comparing value } & \multirow[t]{2}{*}{ Significance 0.05} \\
\hline \multirow{10}{*}{ Form } & Engineers & & & & & \\
\hline & Doctors & 63.31 & 28 & 7.146 & 2.55 & Sig. \\
\hline & Teachers & 62.63 & 28 & 9.885 & 3.23 & Sig. \\
\hline & Students & 62.22 & 28 & 8.864 & 3.64 & Sig. \\
\hline & NGO ms. & 61.31 & 28 & 9.506 & 4.55 & Sig. \\
\hline & Employ & 60.91 & 28 & 11.477 & 4.95 & Sig. \\
\hline & Lawyers & 60.33 & 27 & 10.173 & 5.53 & Sig. \\
\hline & Housewife & 60.02 & 28 & 10.112 & 5.84 & Sig. \\
\hline & Not-occup. & 52.20 & 28 & 8.029 & 13.66 & Sig. \\
\hline & Total & 61.30 & 250 & 9.790 & & \\
\hline \multirow{10}{*}{ Leaning } & Employ. & 35.00 & 28 & 5.524 & & \\
\hline & Students & 34.66 & 28 & 5.117 & 0.34 & Sig. \\
\hline & NGO Ms. & 34.41 & 28 & 5.840 & 0.59 & Sig. \\
\hline & Teachers & 34.02 & 28 & 5.603 & 0.98 & Sig. \\
\hline & Engineers & 33.07 & 27 & 8.642 & 1.93 & Sig. \\
\hline & Lawyers & 33.00 & 27 & 7.036 & 2 & Sig. \\
\hline & Doctors & 32.92 & 28 & 6.525 & 2.08 & Sig. \\
\hline & Housewife & 32.70 & 28 & 7.528 & 2.3 & Sig. \\
\hline & Not-occup. & 26.73 & 28 & 6.530 & 8.27 & Sig. \\
\hline & Total & 33.64 & 250 & 6.290 & & \\
\hline
\end{tabular}

Notably, from the above table can be noticed that the level of Leaning style are higher among an employments and then with less high among students and NGOs members participants with compared to other groups of the sample, leaning (employments; $\mathrm{N}=28, \mathrm{M}=35.00$, std.= 5.524), (students; $\mathrm{N}=28, \mathrm{M}=34.66$, std.= 5.117), (NGO; $\mathrm{N}=28, \mathrm{M}=34.41$, std.= 5.840)]. Regarding the level of Form styles is higher among engineers and then less high among doctors and teachers (Engineers; $\mathrm{N}=27, \mathrm{M}=65.86$, std.= 7.745), (doctors; $\mathrm{N}=28, \quad \mathrm{M}=63.31$, std.= 7.146), (teachers; $\mathrm{N}=28, \mathrm{M}=62.63$, std. $=9.885$ ). On the other hand, the lowest levels of both styles of thinking are reported between housewife and not occupied women, one after the others [(Form (not occupied; $\mathrm{N}=28, \mathrm{M}=52.20$, std.= 8.029), (housewife; $\mathrm{N}=28, \mathrm{M}=60.02$, std.= 10.112)] and [(leaning (not occupied; $\mathrm{N}=28, \mathrm{M}=26.73$, std.=
6.530), (housewife; $\mathrm{N}=28, \quad \mathrm{M}=32.70$, std.= 7.528)]. Overall, the level of the three other styles of thinking were not significant among women, but the level of form and leaning styles of thinking were significant among participants according to occupation and job condition. This result is in agreement with (Osterman, 2015, p. 107-115), (Harrison and Bramson, 2002, p. 510), (Ashoori, Khorshidi and Khosravi, 2015, p. 535-538) who reported that who had better job quality showed more balanced thinking styles and indicated that there was a significant positive correlation between the social security organization managers' thinking styles and their performance.

\subsubsection{Differences in all Styles of Thinking according to Governorates}

The study aimed to examine the statistical difference between all styles of thinking among 
250 participants according to their governorates. Results of One-way ANOVA showed there is no significant main difference between the variable governorates and all styles of thinking; see table
(5). All participants were distributed between two governorates, which are (Erbil and Sulaymaniyeh). For further explanation see appendix
From the above table can be seen that, the Fcalculated value of all styles are smaller than Ftable value [(function; $\mathrm{F}-\mathrm{C}=0.098<\mathrm{F}-\mathrm{T}=$ 2.380), (form; $\mathrm{F}-\mathrm{C}=0.022<\mathrm{F}-\mathrm{T}=2.380$ ), (level; $\mathrm{F}-\mathrm{C}=1.530<\mathrm{F}-\mathrm{T}=2.380),($ scope $; \mathrm{F}-\mathrm{C}=0.119<$ $\mathrm{F}-\mathrm{T}=2.380$ ) and (leaning; $\mathrm{F}-\mathrm{C}=1.910<\mathrm{F}-\mathrm{T}=$ 2.380)] at the degree of freedom 1-248 and the level of significance 0.05 , which means that there are no significant differences in the prevalence rate of all styles of thinking among women according to the place they leave.

\subsection{Examining statistical differences in} variable Self-Image (SI) according to participants' Occupations and Governorates.

Another important aim of the study is examining the statistical difference in Self-image among 250 participants according to factors 'occupations and governorates'. Results of Oneway ANOVA showed there are no significant main difference between neither occupations and self-image or governorates and self-image; see table (6). All participants were distributed between two governorates, which are (Erbil and Sulaymaniyeh). And according to nine (9) different occupations; for further explanation see appendix

(2). 
Table (6) One-way ANOVA to examine statistical differences in self-image according to occupations \& governorates among participants

\begin{tabular}{|c|c|c|c|c|c|c|c|}
\hline \multirow[b]{2}{*}{ Self-Image } & & \multirow[b]{2}{*}{ Sum of Squares } & \multirow[b]{2}{*}{$\mathrm{df}$} & \multirow[b]{2}{*}{ Mean Square } & \multicolumn{2}{|c|}{$\mathrm{F}$ Value } & \multirow[b]{2}{*}{ Sig/0.05 } \\
\hline & & & & & Calculated & Table & \\
\hline \multirow[t]{3}{*}{ Occupation } & Between Groups & 2745.489 & 8 & 343.186 & & & \\
\hline & Within Groups & 50772.127 & 241 & 210.673 & 1.629 & 2.380 & Not/sig \\
\hline & Total & 53517.616 & 249 & & & & \\
\hline \multirow[t]{3}{*}{ Governorates } & Between Groups & 99.856 & 1 & 99.856 & & & \\
\hline & Within Groups & 53417.760 & 248 & 215.394 & 0.464 & 2.380 & Not/sig \\
\hline & Total & 53517.616 & 249 & & & & \\
\hline
\end{tabular}

As it is shown in the above table, the Fcalculated value of both factors are smaller than F-table value (Occupations; $\mathrm{F}-\mathrm{C}=1.629<\mathrm{F}-\mathrm{T}=$ 2.380 , at the degree of freedom 8-241) and (Governorates; $\mathrm{F}-\mathrm{C}=0.464<\mathrm{F}-\mathrm{T}=2.380$, at the degree of freedom 1-248) the level of significance 0.05 , which means that there are no significant differences in the prevalence rate of self-image among women according to occupations and the place or governorates they leave. This result is not in agreement with (Zhang, 2008, p. 255-271) study, which found that those participants who had a strong sense of identity were those who had part-time job with a good quality. However, the result could be in agreement with (Ghezelbash, Rahmani, Peyrovi,
Inanloo \& Shekarchian, 2015, p. 1-5) who reported that the mean score of self-esteem according to different educational achievements and jobs did not differ statistically. However, there are some other factors such as family economic status and marital status could statistically significant influence on people selfconcept.

\subsection{Discovering the relationship between both variables, Thinking Styles (all styles) and Self- Image among participated Women. \\ For aiming the correlation coefficient} between variables self-image and all styles of thinking, the study used Pearson Correlation Coefficient; see table (7).

\begin{tabular}{|c|c|c|c|c|c|c|c|c|}
\hline Variables & $\mathrm{N}$ & Mean & Std. Deviation & $\begin{array}{l}\text { Function } \\
\text { Sig. } 0.01\end{array}$ & $\begin{array}{l}\text { Form } \\
\text { Sig. } 0.01\end{array}$ & $\begin{array}{c}\text { Level } \\
\text { Sig. } 0.01\end{array}$ & $\begin{array}{c}\text { Scope } \\
\text { Sig.0.01 }\end{array}$ & $\begin{array}{l}\text { Leaning } \\
\text { Sig. } 0.01\end{array}$ \\
\hline \multirow{2}{*}{$\begin{array}{l}\text { Self- } \\
\text { image }\end{array}$} & \multirow[t]{2}{*}{250} & \multirow[t]{2}{*}{64.48} & \multirow[t]{2}{*}{6.848} & $0.135^{*}$ & $0.203^{*}$ & 0.059 & 0.044 & 0.079 \\
\hline & & & & Sig. & Sig. & Not/Sig. & Not/Sig. & Not/Sig. \\
\hline Function & 250 & 58.94 & 9.259 & & & & & \\
\hline Form & 250 & 61.30 & 9.790 & & & & & \\
\hline Level & 250 & 38.49 & 6.399 & & & & & \\
\hline Scope & 250 & 37.25 & 7.149 & & & & & \\
\hline Leaning & 250 & 33.64 & 6.290 & & & & & \\
\hline
\end{tabular}

It is clear that there is a positive relationship and statistically significant between self-image and the only two styles of thinking (Function and Form). It mentioned that if the prevalence rate of self-image increase or goes high, also the level of those styles of thinking will also increase or will be high too, and the reverse is also true. This results is in agreement with (Zhang, 2001, p. 100-107) who found that thinking style and self-image are strongly statistically related. Also in another results of a study conducted by (Negahi et al., 2012, p. 75- 
82) showed that thinking styles had a significantly positive relationship with academic self-efficacy of students. As well as, (Zhang, 2008, p. 255-271) reported that not only were thinking styles strongly associated with identity development, but also the former had predictive power for the latter.

\section{RECOMMENDATIONS}

- More attention must be paid to women and provide health care services to protect them from different kind of psychological health problems that they suffer from, as well as, to find a ways and mechanisms to improve the methods to protect them from different psychological pressures that they suffer from.

- Lower self-image and thinking styles could be the result of a combination of some factors. If it is found that more women have low self-image and unbalanced thinking styles than men, then attention should be turned to risk factors. Perhaps, biological and sociocultural differences, life experiences, all accounts. Personality can also play an important part, some people with personality disorders are more prone to negative thinking about their identity.

\section{SUGGESTIONS}

- Future studies are needed to further explore the relation between thinking styles and other different variables such as creativity.

- Future studies are needed to further explore the relation between self-image and other different psychological problems such as being pessimism/ depression/ anxiety or being addicted to social media. As well as, to explore the relation between self-image with some personality disorder, such as borderline personality disorder.

- Future studies are needed to further explore the relation between both variables and other demographic factors such as gender differences/ age/ family economic/ marital status and education.

\section{REFERENCES}

Ackerman, C. (2018, December 22). What Is SelfImage And How Do We Improve It? Definition $+\quad$ Quotes. from https://positivepsychology.com/self-image/

Ackerman, C. (2018, January 1). What Is SelfConcept Theory? A Psychologist Explains. from https://positivepsychology.com/selfconcept/

Albrecht, K. (1983, January 1). Theory Of Thinking Styles (Mindex Theory of Thinking Styles). from

https://www.karlalbrecht.com/mindex/mindext heory.htm

Ashoori, E., Khorshidi, A., \& Khosravi, A. A. (2015). A Survey on Relationship between Thinking Styles and Job Satisfaction on Managers Job Performance. Journal of Applied Environmental and Biological Sciences, 5(10S), 335-540.

Atkinson, R. L., Atkinson, R. C., Smith, E. E., Bem, D. J., \& Nolen-Hoeksema, S. (1996). Hilgard's introduction to psychology (pp. 464465). Fort Worth: Houghton Mifflin Harcourt $\mathrm{P}$.

Bandura, A. (1977). Social Learning Theory. New York: General Learning Press.

Baumeister, R. F. (2010). The Self: Advanced Social Psychology: the state of the science (pp. 139175). Oxford University Press.

Brown, J. D., Dutton, K. A., \& Cook, K. E. (2001). From the top down: Self-esteem and selfevaluation, 15(5), 615-631.

Chaiyapornpattana, N., \& Wongwanich, S. (2013). Development of a multidimensional thinking styles scale based on theory of mental self government for sixth grade students. Research in Higher Education Journal Development, 20(1), 1-10.

Cherry, K. (2018, May 23). What Is Self-Concept And How Does It Form?. from https://www.verywellmind.com/what-is-selfconcept-2795865

Cherry, K. (2019, January 1). What Are Piaget's Four Stages of Development?. from https://www.verywellmind.com/piagetsstages-of-cognitive-development-2795457

Dave, D., \& Rashad, I. (2009). Overweight status, self-perception, and suicidal behaviors among adolescents. Social Science \& Medicine, 68(9), 1685-1691.

Demirbas, O. O., \& Demirkan, H. (2007). Learning styles of design students and the relationship of academic performance and gender in design education. Learning and Instruction, 17(3), 345-359.

Donnellan, M. B., Trzesniewski, K. H., Robins, R. W., Moffitt, T. E., \& Caspi, A. (2005). Low Self-Esteem Is Related to Aggression, Antisocial Behavior, and Delinquency. Psychol Sci, 16(4), 328-335.

Emamipour, S., \& Seyf, A. A. (2004). Revolutional examination of thinking styles in students and scholars, and their relationship with creativity and academic success, (3). 
Ghezelbash, S., Rahmani, F., Peyrovi, H., Inanloo, M., \& Shekarchian, S. (2015). Comparison of Self-Esteem Among First to Fourth Year Nursing Students From Universities of Medical Sciences in Tehran. Thrita, 4(1), 1-5

GirlGuiding (2001). Cosmatic surgery; Guides aim to discourage girls. from https://www.bbc.com/news/uk-12639102

Greenthal, S. (2019, August 8). Body Image and Your Young Adult. from https://www.verywellfamily.com/body-imageand-young-adults-4118371

Harrison, A. F., \& Bramson, R. M. (2002). The art of thinking (p. 240). New York: Berkley Publishing Group.

Heidari, F., \& Bahrami, Z. (2012). The Relationship between Thinking Styles and Metacognitive Awareness among Iranian EFL Learners. International Journal of Linguistics, 4(3), 721-733.

İsmail, N., \& Tekke, M. (2015). Rediscovering Rogers's Self Theory and Personality. Journal of Educational, Health and Community Psychology. 4. 2088-3129.

Jacob, S. E. (1997). Book Review: Offer Self-Image Questionnaire, Revised. Journal of Psychoeducational Assessment, 15(4), 373379.

Lubart, T. I. (1994). Creativity. In R. J. Sternberg (Ed.), Handbook of perception and cognition (2nd ed.). Thinking and problem solving ( $\mathrm{p}$. 289-332). Academic

Press. https://doi.org/10.1016/B978-0-08057299-4.50016-5

McLeod, S. (2008, January 1). Self Concept | Simply Psychology. from

https://www.simplypsychology.org/selfconcept.html

McLeod, S. (2019, January 1). Sampling Methods. from https://www.simplypsychology.org/selfconcept.html

Moulton, S. (1970, January 1). Theories Of SelfEsteem: Early \& Modern - Video \& Lesson Transcript | Study.com. from https://study.com/academy/lesson/theories-ofself-esteem-early-modern.html

Negahi, M., Ghashghaeizadeh, N., \& Hoshmandia, M. (2012). The Study of the Relationship between Learning Styles and Thinking Styles with Academic Self-efficacy in English lesson among the Students of Islamic Azad University of Behbahan. Journal of Life Science and Biomedicine, 3(1), 75-82.

Omar, A. (2010). Anfal campaigns and their impacts on economic, social, psychological conditions of the remained survived women. The Swedish Parliament Stockholm: north of Kurdistan.
Osterman, M. D. (2015). Exploring Relationships Between Thinking Style and Sex, Age, Academic Major, Occupation, and Levels of Arts Engagement Among Professionals Working in Museums. Florida International University FIU Digital Commons, 107-115. https://doi.org/10.25148/etd.fidc000174

Pinquart, M., \& Sorensen, S. (2001). Gender Differences in Self-Concept and Psychological Well-Being in Old Age: A Meta-Analysis. The Journals of Gerontology Series B: Psychological Sciences and Social Sciences, 56(4), P195-P213.

Rogers, C. R. (1959). A Theory of Therapy, Personality, and Interpersonal Relationships, as Developed in the Client-Centred Framework. Psychology: A Study of A Science, 3(1), 184-256.

Rosenberg, M. (1965). Society and the Adolescent Self-Image (pp. 104-105). Princeton University Press.

Saideh, M., Omid, R., Nazanin, N., Hadis, H., \& Katayoun, T. (2014). The Relationship between Thinking Style and Gender in High School Students. 3(12), 1-4.

Salters-Pedneault, K. (2019, August 31). Borderline Personality Disorder and Identity Problems . from https://www.verywellmind.com/borderlinepersonality-disorder-identity-issues-425488

Savi-Cakar F., \& Savi-Karayol, S. (2015). The Impact of Body Image and Self-Esteem on Turkish Adolescents' Subjective Well-Being. $J P R$, 5(9), 536-551.

Stangor, C. (2011). Research methods for the behavioural sciences (4th ed.). Mountain View, CA: Cengage.

Steiger, A. E., Allemand, M., Robins, R. W., \& Fend, H. A. (2014). Low and decreasing self-esteem during adolescence predict adult depression two decades later. Journal of Personality and Social Psychology, 106(2), 325-338.

Sternberg, R. J. (1988). Mental Self-Government: A Theory of Intellectual Styles and Their Development. Human Development , 31(4), 197-224.

Sternberg, R. J. (1997). Thinking styles. New York, NY, US: Cambridge University Press.

Sternberg, R. J., \& Wagner, R. K. ( (1994). Mind in context: Interactionist perspectives on human intelligence. Cambridge University Press.

Tajfel, H., \& Turner, J. (1979). “An Integrative Theory of Intergroup Conflict.”. In The Social Psychology of Intergroup Relations (pp. 3347). England: Brooks/Cole.

Van Dalen, D. (1979). Understanding Educational Research: An Introduction. An Introduction (4th ed.). New York York: McGraw-Hill Book 
Company, 1979. Pp. 547. British Journal of

Educational Studies, 28(2).

Vinney, C. (2019, July 22). Understanding Social Identity Theory And And Its Impact On Behavior. from https://www.thoughtco.com/social-identitytheory-4174315

Wechsler, S. (2009). Age and gender impact on thinking and creating styles, 2(1), 37-48. https://doi.org/10.1037/e511412008-001

\begin{tabular}{|c|c|c|c|}
\hline Appenalx (2 & $\begin{array}{l}\text { Demographical } \\
\text { Factors }\end{array}$ & Variables & Numbers \\
\hline \multicolumn{2}{|r|}{ 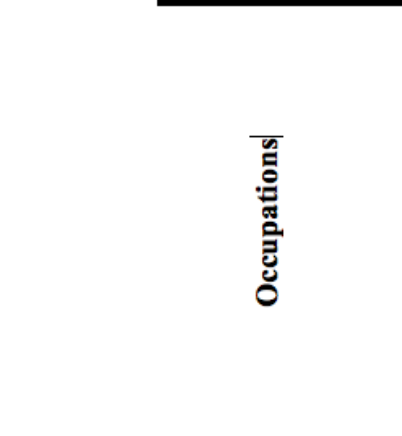 } & $\begin{array}{l}\text { Doctors } \\
\text { Engineers } \\
\text { Lawyers } \\
\text { Teachers } \\
\text { Employments } \\
\text { NGOs } \\
\text { Students } \\
\text { Housewife } \\
\text { Not-Occupied } \\
\text { Total }\end{array}$ & $\begin{array}{l}28 \\
27 \\
27 \\
28 \\
28 \\
28 \\
28 \\
28 \\
28 \\
250\end{array}$ \\
\hline \multicolumn{2}{|r|}{$\dot{\vec{b}}$} & $\begin{array}{l}\text { Erbil } \\
\text { Suleymaniyeh } \\
\text { Total }\end{array}$ & $\begin{array}{l}125 \\
125 \\
250\end{array}$ \\
\hline II & & $m$ & \\
\hline
\end{tabular}

(3) The Scale of Thinking Styles-Shorted Version

\begin{tabular}{|c|c|c|c|c|c|c|}
\hline $\mathrm{N}$ & Items & $\begin{array}{c}\text { Very } \\
\text { significantly } \\
\text { well }\end{array}$ & $\begin{array}{l}\text { To a Moderate } \\
\text { degree well }\end{array}$ & $\begin{array}{l}\text { To a Small } \\
\text { extent well }\end{array}$ & $\begin{array}{l}\text { To a very limited } \\
\text { extent well }\end{array}$ & $\begin{array}{l}\text { Not at } \\
\text { all well }\end{array}$ \\
\hline 1. & $\begin{array}{l}\text { I like projects where I can study and rate different } \\
\text { views or ideas. }\end{array}$ & & & & & \\
\hline 2. & $\begin{array}{l}\text { I like tasks and problems that have fixed rules to follow } \\
\text { in order to complete them. }\end{array}$ & & & & & \\
\hline 3. & I like projects that I can complete independently. & & & & & \\
\hline 4. & $\begin{array}{l}\text { I prefer situations where I can carry out my own ideas, } \\
\text { without relying on others. }\end{array}$ & & & & & \\
\hline 5. & $\begin{array}{l}\text { When making decisions, I tend to rely on my own ideas } \\
\text { and ways of doing things. }\end{array}$ & & & & & \\
\hline 6. & $\begin{array}{l}\text { I like situations where I can focus on general issues, } \\
\text { rather than on specifics. }\end{array}$ & & & & & \\
\hline 7. & $\begin{array}{l}\text { Before starting a project, I like to know the things I } \\
\text { have to do and in what order. }\end{array}$ & & & & & \\
\hline 8. & $\begin{array}{l}\text { When working on a project, I like to share ideas and } \\
\text { get input from other people }\end{array}$ & & & & & \\
\hline & $\begin{array}{l}\text { I enjoy working on things that I can do by following } \\
\text { directions. }\end{array}$ & & & & & \\
\hline & $\begin{array}{l}\text { When discussing or writing down ideas, I follow formal } \\
\text { rules of presentation. }\end{array}$ & & & & & \\
\hline
\end{tabular}


to me first.

12. In talking or writing down ideas, I like to show the scope and context of my ideas, that is, the general picture

13. I like situations where I can compare and rate different ways of doing things.

14. When faced with opposing ideas I like to decide which is the right way to do some- thing.

15. In discussing or writing on a topic, I think the details and facts are more important than the overall picture.

16. I prefer to deal with specific problems, rather than with general questions

17. I prefer tasks or problems where I can grade the designs or methods of others.

18. I enjoy work that involves analyzing, grading, or comparing things.

19. I dislike problems that arise when doing something in the usual, customary way.

20. When I start on a task, I like to consider all possible ways of doing it, even the most ridiculous.

21. In trying to finish a task, I tend to ignore problems that come up.

22. I like to deal with major issues or themes, rather than details or facts.

23. When working on a task, I like to start with my own ideas.st:

24. When faced with a problem, I use my own ideas and strategies to solve it: isp:

25. When discussing or writing down ideas, I stress the main idea and how everything fits together.

26. When working on a task, I can see how the parts relate to the overall goal of the task.

27. I like to participate in activities where I can interact with others as a part of a team.

28. I like projects that have a clear structure and set plan and goal.

29. When there are many important things to do, I try to do as many as I can in whatever time I have.

30. I can switch from one task to another easily, because all tasks seem to me to be equally important.

31. When trying to make a decision, I try to take all points of view into account.

32. I like to take old problems and find new methods to solve them.

33. I like projects in which I can work together with others.

34. I like to collect detailed or specific information for projects I work on.

35. When discussing or writing down ideas, I like criticizing others' ways of doing things.

36. I like to change routines in order to improve the way tasks are done.

37. I have to finish one project before starting another one.

38. When making a decision, I try to take the opinions of others into account.

39. I like situations where I can use my own ideas and ways of doing things.

40. I like problems where I need to pay attention to details.

41. I care more about the general effect than about the details of a task I have to do.

42. I like situations where I can try new ways of doing things.

43. I tend to emphasize the general aspect of issues or the overall effect of a project.

44. If there are several important things to do, I do the one 
most important to me.

45. When trying to make a decision, I rely on my own

judgment of the situation.sis

46. I like to challenge old ideas or ways of doing things and

to seek better ones.

47. I like to work alone on a task or a problem.

48. I like situations where the role I play is a traditional one.

49. I feel happier about a job when I can decide for myself what and how to do it. is:

50. I like to do things in ways that have been used in the past.

51. When starting a task, I like to brainstorm ideas with friends or peers.

52. I like to do things in new ways not used by others in the past.

53. I like situations where I interact with others and everyone works together.

54. When faced with a problem, I like to work it out by myself.

55. When discussing or writing down ideas, I follow formal rules of presentation.

56. I like to control all phases of a project, without having to consult with others. isp:

57. Before starting a task, I like to figure out for myself how I will do my work.

58. I like situations where I can focus on general issues, rather than on specifics.

59. When I'm in charge of something, I like to follow methods and ideas used in the past.

60. In a discussion or report, I like to combine my own ideas with those of others.

Appendix (4) The Scale of Self-Image

$\mathbf{N} \quad$ Items Do not
describe Rarely Sometimes describe describe me Most of the Completely me at all me

time describe me describe

me

\begin{tabular}{|c|c|}
\hline 2 & Jove to help other people whenever they need me \\
\hline 3 & I respect myself. \\
\hline 4 & I criticize others even I know that I was wrong. \\
\hline 5 & $\begin{array}{l}\text { I find it hard to make new friends or to make social } \\
\text { relationship. }\end{array}$ \\
\hline 6 & People just do not respect me and makes fun of me. \\
\hline 7 & I can make decision. \\
\hline 8 & I am calm when others criticize me. \\
\hline 9 & $I$ isolate myself from others. \\
\hline 10 & I like my face and body. \\
\hline 11 & $\begin{array}{l}\text { Whenever something goes wrong, I try to find out what I } \\
\text { can do to avoid another mistake. }\end{array}$ \\
\hline 12 & I am not satisfied with my face and body-shape. \\
\hline 13 & I feel nervous. \\
\hline 14 & Other people just do not like me. \\
\hline 15 & I am not satisfied of myself. \\
\hline 16 & At work I am one of the best. \\
\hline 17 & I like taking part in family decisions. \\
\hline 18 & I feel lonely. \\
\hline 19 & I do not like the other sex. \\
\hline 20 & I feel strong and healthy. \\
\hline 21 & I feel I have no talent at all. \\
\hline 22 & I avoid looking at myself in the mirror. \\
\hline 23 & I avoid being photographed or videotaped. \\
\hline 24 & $\begin{array}{l}\text { I avoid physical contact (i.e., hugging) because of the size } \\
\text { or shape of my body. }\end{array}$ \\
\hline
\end{tabular}

